\title{
House price-stock price relations in Thailand: an empirical analysis
}

\begin{abstract}
Purpose: The purpose of this paper is to empirically evaluate the wealth and credit-price effects in the relations between housing prices and stock prices for Thailand using quarterly data from 1995 to 2006.

Design/methodology/approach: The analysis relies on a four-variable vector autoregression (VAR) framework consisting of house prices, stock prices, real output and consumer prices. Granger causality tests, impulse-response functions and variance decompositions simulated from the estimated VAR systems are adopted as bases for inferences.

Findings: The results obtained from Granger causality tests, impulse-response functions and variance decompositions all suggest a unidirectional causality that runs from stock prices to house prices. Thus, the wealth effect is unequivocally supported for the Thai case. The paper also documents the importance of real activity in influencing both house and stock prices. Likewise, stock prices do exert significant effects on real output and to some extent the general price level. These results have an implication that stock market stability is critical for the stability of the housing market as well as the goods market.

Originality/value: The paper provides an emerging market perspective on stock price $i$ house price relations, which seem to be lacking in the literature.
\end{abstract}

Keyword: Housing; Prices; Stock prices; Autoregressive processes; Thailand 